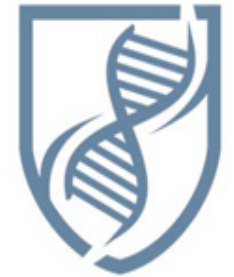

Journal of Bioscience and Applied Research

\section{JBAAR}

WWW.JBAAR.ORG

\title{
Effect of feeding Silkworm (Bombyx mori L.) on Mulberry treated with Bio and Inorganic Fertilizer on Antennal Sensilla
}

\author{
Gaaboub, I*. A.; Amira M. El-Shewy * and Magda A, Salem** \\ *Faculty of Agriculture, Banha University, Department of Plant Protection \\ ** Faculty of Agriculture, Alexandria University, Department of Applied Entomology \\ (Corresponding author-e mail: ibrahim.gaabwob@fagr.bu.edu.eg)
}

\begin{abstract}
The present work was directed to study the effect of bio and inorganic fertilizer treatments on the ultra structure antennae of female and male silkworm (Bombyx mori L.), as a trail to understand the effect of the type of fertilization on mulberry trees and silkworm antennal sensilla. The sensory organs on the antennae were visualized by scanning electron microscopy. The results showed that the surface of the antenna is covered with scales overlapped together and is provided with sense sensilla that found on the ventral and lateral surface of the antenna. On the silkmoth antennae, six different types of sensilla have been identified: Olfactory sensilla trichodea, s. basiconica, s. coeloconica, putative gustatory s. chaetica that are multimodal receptors, s. styloconica, that are thought to be thermo- and hygroreceptors and the mechano-sensory sensilla (squamiformia). Silkworm (B. mori) is a monophagous insect that drives almost all required nutrients for its growth and development from mulberry leaf. Mulberry trees were treated with bio fertilizes, chemical fertilizers and the mixture of them through the addition in soil. The results of chemical fertilizer, bio-fertilizer and its mixture increased the growth, development, health, feed consumption and larval weight, total larval duration and this reflected on the number and length of sensilla. Chemical fertilizer, biofertilizer and its mixture increased the size of sensilla than control. Moreover, application by bio-fertilizer resulted in better values larval weight, total larval duration and the size of sensilla. Both chemical and bio fertilizes exhibited better values for pupal weight which reflect on the size of sensilla. Keywords: Silkworm, Bombyx mori, Antenna, Sense organs, SEM, Mulberry leaf, Bio-fertilizers, Inorganic fertilizers.
\end{abstract}

\section{Introduction}

Insects, like other invertebrate and vertebrate animals have evolved chemical sensing devices for detecting stimuli that have adaptive value, so that most of their receptors are sensitive to a specific range of available stimuli and this sense has become further differentiated into two categories ie. chemo and mechano receptors (Tousson and Gaaboub, 2004 and Gaaboub and Tousson, 2010). The antennal or tarsal receptors could influence the various modes of behaviour including avoidance (White \& Chapman, 1990; Gaaboub, 2000; and Gaaboub et al., 2005), detection and selection of food sources (Blaney, 1974; Gaaboub and Hustert, 1998) and selection oviposition sites (Staedler et al., 1995; Kalogianni, 1996; Tousson et al., 1999; Newland et al., 2000).

Forty years of studying insect sensilla with the electron microscope have resulted in a general bauplan thatlike a theme with variations-extends throughout all insect orders. Typical modality-specific features of the cuticular apparatus and of the receptor cell endings in many cases allow for correct prediction of the functional modality of a sensillum type before electrophysiological recording can yield final confirmation (Hunger and Steinbrecht, 1998).

The morphology and distribution of the sensilla present on some insect appendages as antennae and tarsi have been studied in different species of Lepidopterous insects, e.g., Agrotis segetum (Hallberg, 1981), Yponomeuta vigintipunctatus (Cuperus, 1983 and 1985a), Manduca sexta (Shields and Hildebrand, 2001). 
The domesticated silkworm, B. mori L., is a monophagous insect that can be raised on fresh mulberry leaves (Morus alba L.). Good quality leaf production in mulberry is highly dependent on the supply of various inputs especially nitrogen and phosphorus fertilizers (Nasreen et al., 1999 and El-Khayat et al., 2013). The quality of mulberry leaf fed to silkworms is the most important factor that influences successful cocoon production (Singheal et al., 1999). Usage of a combination of organic and inorganic fertilizers, increasing the carbohydrate and crude protein percentage of the mulberry leaves significantly increased the silkworm larval body weight, silk gland weight and ultimately the cocoon yield etc (Jadhav et al., 2000).

The present studies aims to determine the impact of bio-fertilizers, inorganic fertilizers application and their mixture on the ultra structure antennae sensilla of female and male silkworm (B. mori), as a trail to understand the relation between different fertilizers on mulberry trees and antennal sensilla

\section{Materials and Methods}

\section{Rearing technique}

The mulberry silkworm (B. mori) eggs were obtained from the Sericulture Research Department of Plant Protection Research Institute, Agricultural Research Center, Ministry of Agriculture and Land Reclamation in Giza, Egypt. It was established in the Department of Plant Protection, Faculty of Agriculture Moshthour, Benha University and the department of applied Entomology, Faculty of Agriculture, Alexandria University during two successive spring seasons (2014 and 2015).

\section{Nutrition methods and Food intake}

The native mulberry (Morus alba var rosa) leaves were used to feed the mulberry silkworm larvae. Mulberry trees were treated with bio fertilizes, chemical fertilizers and the mixture of them through the addition in soil. Two bio-fertilizers were used; nitrogen containing Azotobacter spp. and Azosprillum spp. and phosphoren contains Bacillus magatherium. Also, chemical fertilizers were used as Nitrogen in the form of Urea $(46 \% \mathrm{~N})$, phosphorus in the form of super phosphate $\left(16 \% \mathrm{P}_{2} \mathrm{O}_{5}\right)$ and potassium in the form of potassium sulphate $\left(48 \% \mathrm{~K}_{2} \mathrm{O}\right)$. Treatments of biofertilizes, chemical fertilizers and their mixture were as shown in table (1).

\section{Bioassay tests of Silkworm (B. mori)}

The newly hatched silkworm larvae were divided into ten groups including control. Each treatment represented by three replicates. Each replicate have 50 larvae. For each group, chopped leaves were offered four times daily to young silkworms (first, second and third instars). While, whole leaves were offered for grown silkworm (fourth and fifth instars). The following characters were studied: fresh cocoon weight (FCW), cocoon shell weight (CSW), pupal weight (PW).

\section{Scanning Electron Microscopy (SEM)}

To identify the different sensory receptors on the antenna of the female and male silkworm (B. mori) moths were immersed in hexane and shaked for several minutes to remove the cuticular wax layer. Antennae rinsed in chloroform, dehydrated in ethanol and air-dried. After drying, they were sputtering coated with gold-palladium and examined using a scanning electron microscope (LEO -UIF: Leo 438VP) of Faculty of Science, Alexandria University.

\section{Statistical Analysis}

The statistical analysis was carried out using ANOVA with two factors under significance level of 0.05 for the whole results using SPSS (ver. 19) and complete randomized design were used according to (Steel et al., 1997). Multiple comparisons were carried out applying LSD.

\section{Results and Discussion}

In the silkmoth, the flagella are comb-shaped (Fig. 1) and the antennae of the male are somewhat larger than those of the female. Antenna $5 \mathrm{~mm}$ long and $1.2 \mathrm{~mm}$ width. Usually, the distal part, the flagellum is most prominent. The antennae have two rows of antennal branches (ribs), the shorter anterior and the longer posterior branches. Each rib ca. $68 \mu \mathrm{m}$ wide. The shape can be thought of as an adaptation to optimise odorant catch. The males are described as having denser sensory hairs.

Scanning electron microscopy showed that flagellum is covered by many types of sensilla (Figure $3 \mathrm{~B} \& \mathrm{C}$ ). Sensilla can usually be classified by their external appearance (Fig. 3). For example, olfactory sensilla generally have small pores or slits in their cuticular wall. These opening provide an interface between the inside and the outside to allow the exchange of odorant molecules. Six different types of sensilla have been identified: sensilla trichodea, sensilla basiconica, sensilla coeloconica sensilla chaetica, sensilla styloconica, and sensory sensilla squamiformia (Kaissling et al., 1978; Steinbrecht, 1988 and 1989; Pophof, 1997; Hunger and Steinbrecht, 1998).

\section{- Sensilla coeloconica}

On the silkmoth antenna, the s. coeloconica (pit pegs) stand on the outer side of the basketlike flagellum and the dorsal side of each branchs and stem. The most proximal segments of flagellum are devoid of them (Fig. 2 A-D). The coeloconic sensilla of $B$. mori double-walled, wall-pore sensilla are $10 \mu \mathrm{m}$ long, located in pits, and longitudinally grooved in their distal half (grooved surface $30 \mu \mathrm{m}^{2}$ ). 


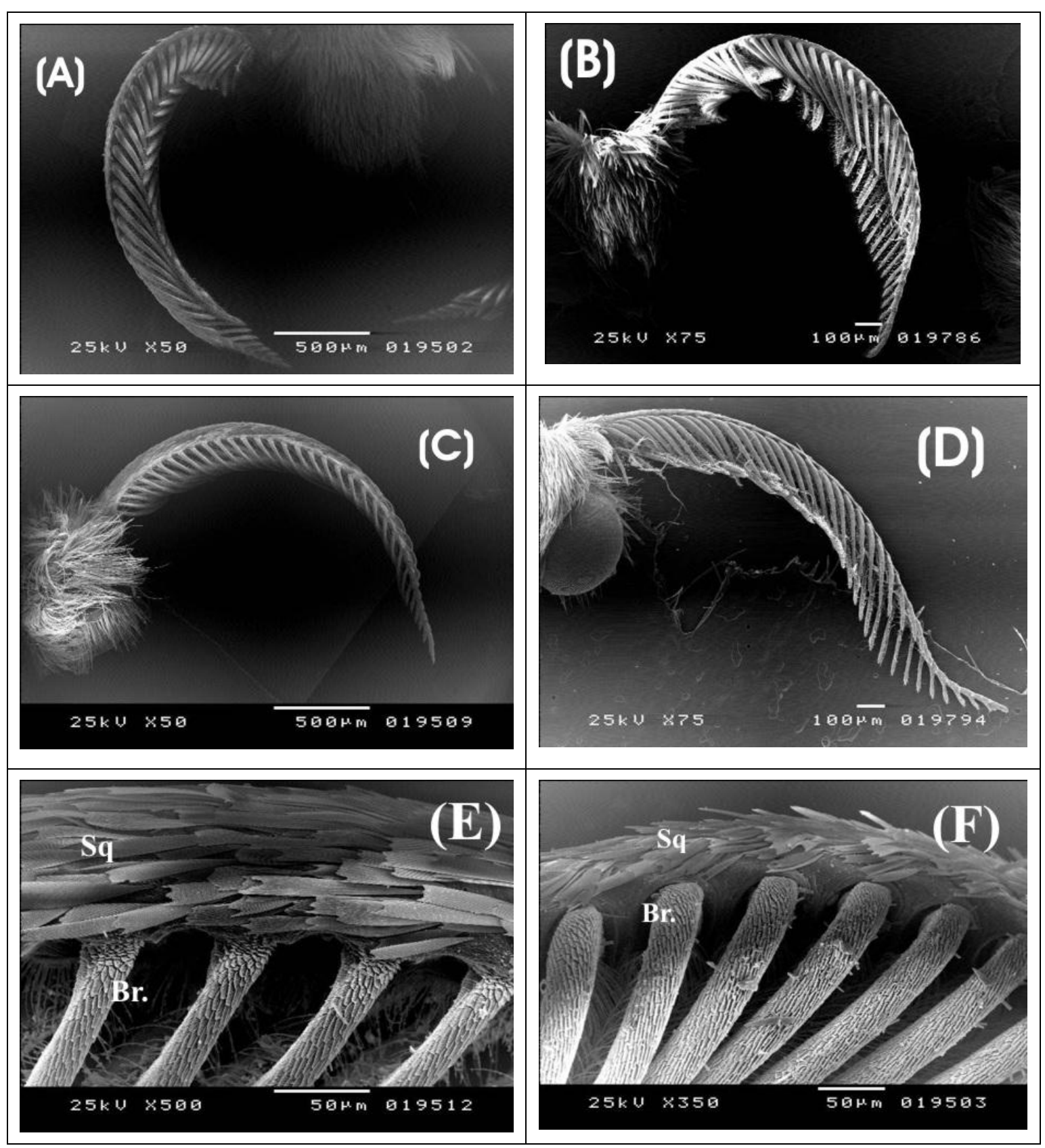

(Fig. 1): External morphology of silkmoth antennae by means of scanning electron microscopy (SEM). (A) External aspect of the head male and female capsule and the antennae (A\&C as control) (B\&D) feeding on fetilized mulberry by chemical fertilizer 400 gN $+300 \mathrm{gP}+250 \mathrm{gK}$, respectively. Structure of a branch of female and male the flagellum (E\&F) bearing numerous sensillar hairs, respectively. 

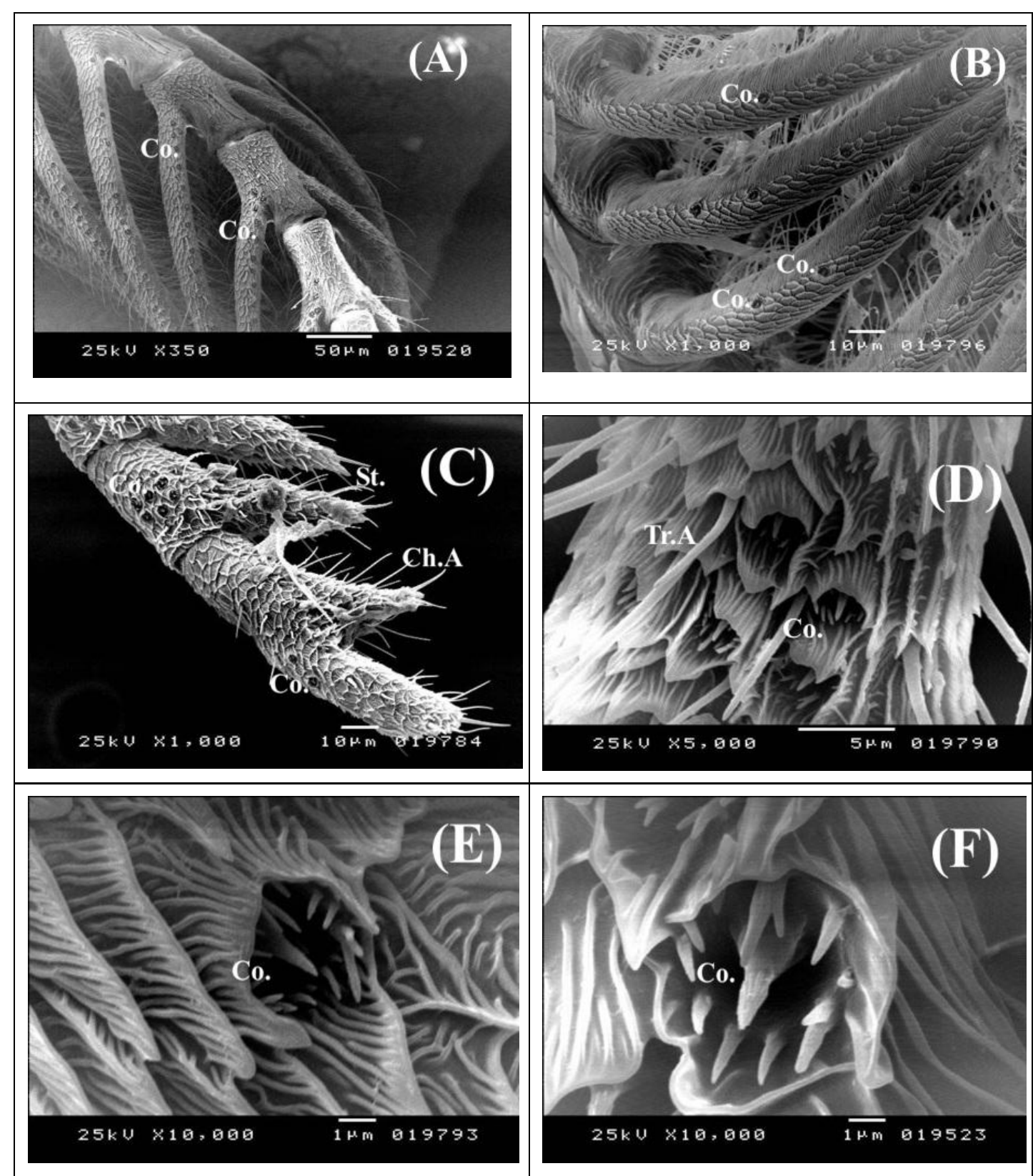

Fig. 2): B. mori, scanning electron micrograph showing tip of antennal branch and branches with sensilla coleonica (Co.) in the grooves, sensilla basiconic (Ba.) and sensilla tricodium (Tr.) this samples treated with mixtures fertilizers (260gN+195gP $+250 \mathrm{gK}+500 \mathrm{gNitroben}+150 \mathrm{~g}$ Phosphorin) female (B\&C) and male fertilized by chemical fertilizers 400gN+300gP+250gK (A,D,E\&F). 
Their number increases reaching to the maximum in the distal third of the antenna. The total number of pit pegs per antenna is between 580 and 790 (mean of 5 male and 5 female antennae: $694+48$ ). The numbers of sensilla on the right and left antenna of the same individual differed by 3-5 $\%$ of the total. The sensilla coeloconica in the silk moth, $B$. mori, show no sexual dimorphism (Hunger and Steinbrecht, 1998). Bio-fertilizers increased the size of sensilla coeloconica (Tables 2\&3).

\section{-Sensilla styloconica}

The sensilla styloconica of $B$. mori are slender located in narrow grooves at the very tip of the antennal branches (Fig. $3 \mathrm{E} \& \mathrm{~F}$ ). Only the most proximal branches of the antenna bear no styloconic sensilla. There may be one, two or three on a single branch tip. A few of them are located on a prominent stylus amidst the sensillum field of the sensilla trichodea and sensilla basiconica (Steinbrecht 1989). Sensilla styloconica per antenna are about 86 sensilla. Different fertilizers and their mixtures affected the size of sensilla styloconica of both sexes of mulberry silkworm (Tables 2\&3). The size of sensilla showed significant difference between control, chemical, biofertilizers and their mixture. Bio-fertilizers increased the size of sensilla styloconica compared with the control (Tables 2\&3).

\section{-Sensilla basiconica}

Sensilla basiconica are peglike or conelike process characterized by: short, have a thinner cuticular wall pitted by a higher density of pores, have a larger number of pore tubules and have many distal dendritic branches. They are arranged in oblique linear rows along the base of deep furrows. The antennal flagellum of female and male B. mori bears two types of basiconic sensilla. The first type averaged $22.1 \& 23.3 \mu \mathrm{m}$ in length, while the second type averaged $15.1 \& 16.11 \mu \mathrm{m}$ in length, respectively.There are two types of basiconic sensilla, type-A and $B$. The fine structure of the basiconic sensilla of female $M$. sexta most closely resembles that of the large basiconic sensilla of female and male B. mori (Steinbrecht, 1973,1980; Steinbrecht and Gnatzy, 1984), males of M. sexta (Keil, 1989; Lee and Strausfeld, 1990), Antheraea polyphemus and A. pernyi (Keil, 1984a), and Y. vigintipunctatus and $A$. orana (Cuperus, 1985a \&b). Bio-fertilizers increased the size of sensilla basiconic type A\&B compared with the control (Fig. 3B\&D. Tables 2\&3).

Comparisons between type-A and type-B basiconic sensilla reveal a sexual dimorphism. Type-A basiconic sensilla of males are longer, with wider base diameter and typically are innervated by either two or three sensory cells with branched dendrites. Type-B basiconic sensilla of males are shorter and typically innervated by one, two, or three branched sensory cells. In contrast, both types of basiconic sensilla of females are innervated by three sensory cells with branched dendrites. The basiconic sensilla of female A. orana (Den Otter et al., 1978) and Yponomeuta species (Van der Pers and Den Otter, 1978) are reported to be sensitive to plant odors, as are similar sensilla of both sexes of $B$. mori and male A. pernyi and Sphinx pinastri (Schneider and Steinbrecht, 1968). The two types of basiconic sensilla of female $M$. sexta were not physiologically characterized. Based on their similarity to morphologically or physiologically characterized female olfactory basiconic sensilla of other insects, these sensilla of female $B$. mori may also be olfactory and possess sensory cells tuned to plant odors.

\section{-Sensilla trichodeum}

The trichoid sensilla are hair like with single multiporous walled (Fig 3 A-E). The antennal flagellum of female and male $B$. mori bears two typs trichoid sensilla. The first type averages $34.1 \& 35.04 \mu \mathrm{m}$ in length and is innervated by two sensory cells. The second type averages $26.1 \& 27.06 \mu \mathrm{m}$ in length, respectively. The sensilla have a diameter of $4 \mu \mathrm{m}$ near the base of the sensillum, and tapers to $1 \mu \mathrm{m}$ at the tip (Fig. $3 \mathrm{~B} \& \mathrm{D}$ ). The type-B trichoid sensillum is slightly shorter than the type-A trichoid sensillum and averages $26.1 \mu \mathrm{m}$ in length. This sensillum has a diameter of $2 \mu \mathrm{m}$ near its base, and tapers to $0.4 \mu \mathrm{m}$ at the tip. The fine structure of type-A trichoid sensilla in females is very similar to the long, pheromone sensitive type A trichoid sensilla of males. In that both are taller than type-B trichoid sensilla of females or type B trichoid sensilla of males, have cuticular shafts with a similar base diameter, have cuticular walls that are thinner than those of type-B trichoid sensilla, have similar transverse plates on the cuticular shaft that are pitted by pores, each pore associated with a similar number of pore tubules that extend into the shaft lumen and are innervated by two sensory cells with unbranched distal dendrites (Sanes and Hildebrand, 1976; Keil, 1989; Lee and Strausfeld, 1990).

The fine structure of the trichoid sensilla of female $M$. sexta very closely resembles that of the trichoid sensilla of female and male B. mori (Steinbrecht, 1973, 1980; Steinbrecht and Gnatzy, 1984), males of M. sexta (Keil, 1989; Lee and Strausfeld, 1990), Antheraea polyphemus and A. pernyi (Keil, 1984a), Yponomeuta vigintipunctatus, Adoxophyes orana, and female Yponomeuta cagnagellus (Cuperus, 1985a).

The fine structure of type-B trichoid sensilla of females is comparable to that of type-B trichoid sensilla of males. Both are shorter than the type-A trichoid, they are similar in length, have a similar base diameter, have a wall thickness similar to that of type-A trichoid and have pores that are associated with a similar number of pore tubules that do not extend to the shaft lumen (Sanes and Hildebrand, 1976; Keil, 1989; Lee and Strausfeld, 1990). Studies by Cuperus (1983) and Cuperus et al. (1983) revealed a sexual dimorphism with respect to the number of trichoid and basiconic sensilla in eleven species of small ermine moths (Yponomeuta spp). Bio-fertilizers increased the size of trichoid sensilla A\&B (Tables 2\&3).

\section{- Sensilla chaetica}

Sensilla chaetica are long, stiff, ridged hair-like structures without wall pores that are set into a socket at the base and radially distributed in whorls at the flagellar margins. They are scattered at the proximal (long) and distal (short) branches of each flagellar segment (Fig. 3 F, G\&H. Table $2 \& 3$ indicated that the Bio-fertilizers increased the size of sensilla chatica. Sensilla chaetica (both long and short) are 

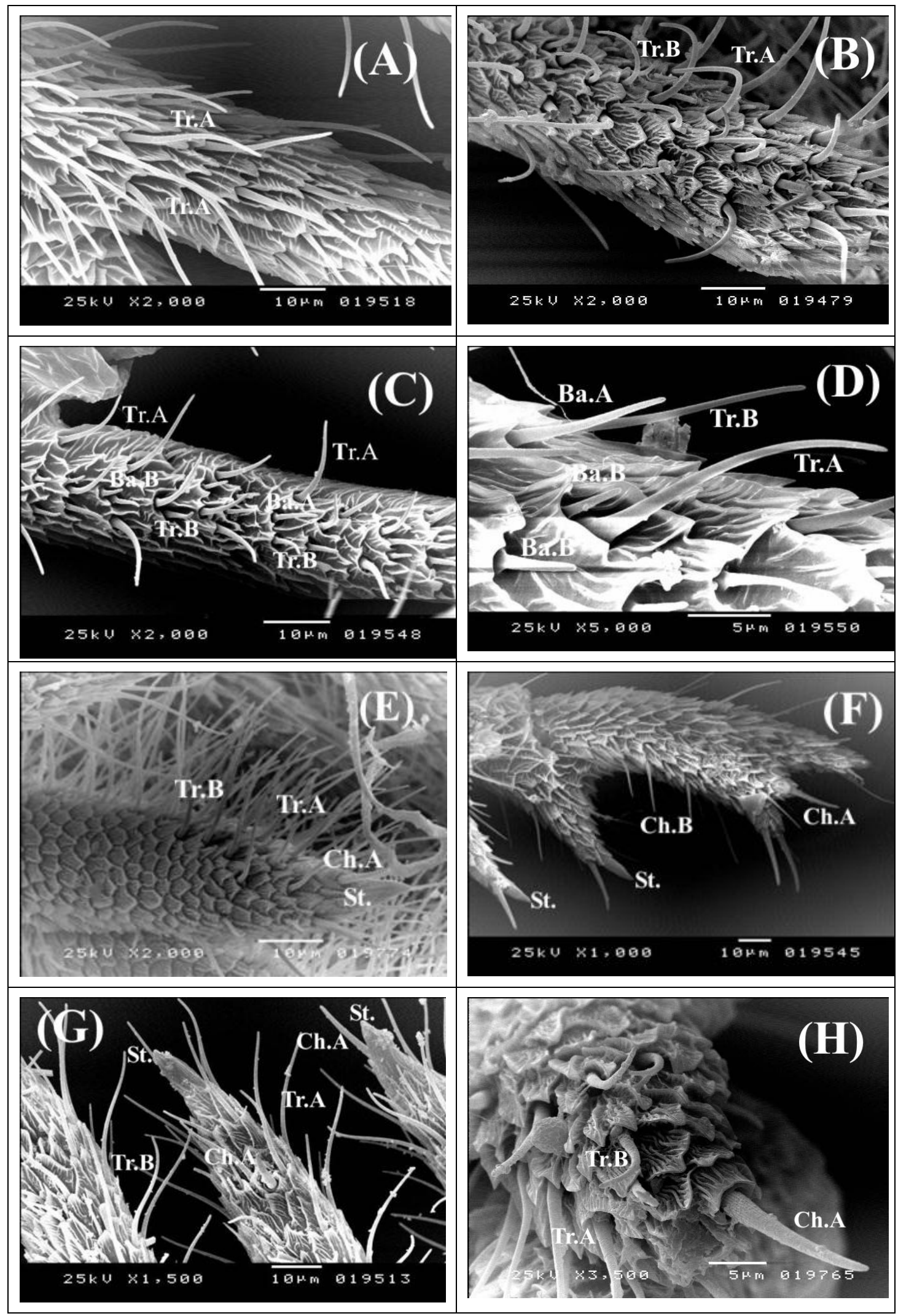

Fig. (3): B. mori, scanning electron micrograph showing tip of female antennal branch and branches with sensilla trichodium (Tr.) and basiconic (Ba). as male control (A) and the treated by biofertilizer $500 \mathrm{~g}$ Nitrogen $+150 \mathrm{~g}$ Phosphorin (B). Female sensilla trichodium and basiconic A\&B (C\&D) treated by chemical fertilizer $400 \mathrm{gN}+300 \mathrm{gP}+250 \mathrm{gK}$. Male sensilla styloconica (St.) which are protected by s. chaeticum (ch), trichodea (Tr.) (E, F, G \& H). 
Table (1): Ingredients of different fertilizers on Mulberry (Morus alba L.) used for feeding larval silkworm (B. mori L).

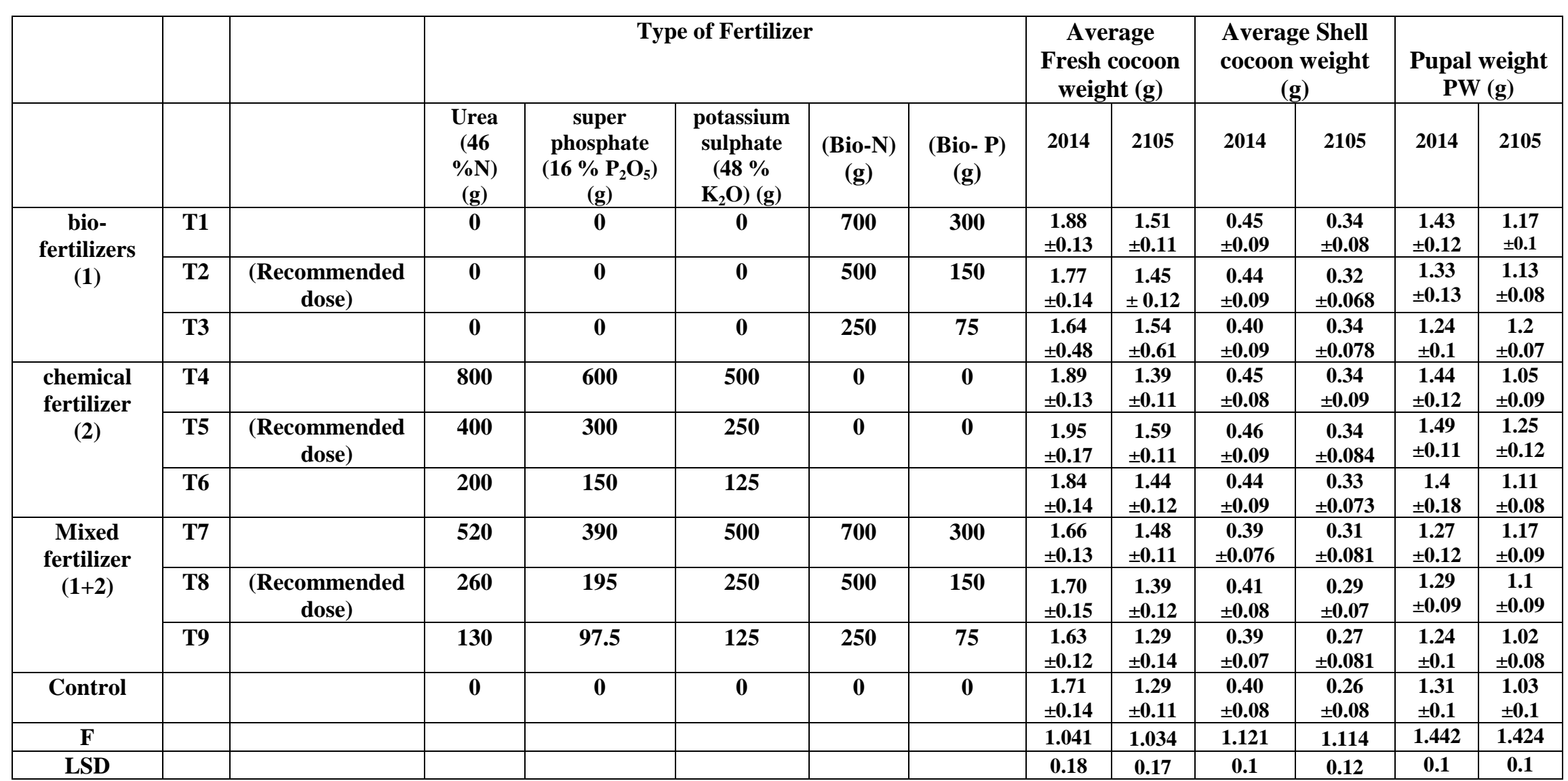


Table (2): Effect of different fertilizers on length $(\mu \mathrm{m})$ of different types of sensilla female $B$. mori L. during 2014 \& 2015 seasons

\begin{tabular}{|c|c|c|c|c|c|c|c|c|c|c|c|c|c|c|c|c|c|}
\hline \multirow{3}{*}{$\begin{array}{c}\text { Type } \\
\text { fertilizer }\end{array}$} & & \multicolumn{4}{|c|}{ Sensilla trichodea } & \multicolumn{4}{|c|}{ S. basiconica } & \multicolumn{2}{|c|}{ S. Coeloconica } & \multicolumn{4}{|c|}{ S. chaetica } & \multicolumn{2}{|c|}{ S. styloconica } \\
\hline & & \multicolumn{2}{|c|}{ Type A } & \multicolumn{2}{|c|}{ Type B } & \multicolumn{2}{|c|}{ Type A } & \multicolumn{2}{|c|}{ Type B } & \multirow[b]{2}{*}{$\underset{\text { ন }}{\mathbb{J}}$} & \multirow[b]{2}{*}{ 옹 } & \multicolumn{2}{|c|}{ Type A } & \multicolumn{2}{|c|}{ Type B } & \multirow[b]{2}{*}{$\underset{\text { ป }}{\stackrel{\Xi}{*}}$} & \multirow[b]{2}{*}{ 옹 } \\
\hline & & $\stackrel{\nabla}{\stackrel{乛}{*}}$ & 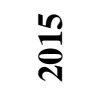 & $\frac{\nabla}{\text { จ }}$ & 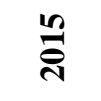 & $\frac{\nabla}{\stackrel{\sim}{*}}$ & 눙 & 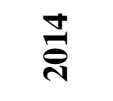 & $\stackrel{10}{\stackrel{2}{2}}$ & & & 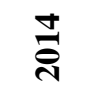 & 농 & 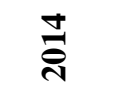 & 농 & & \\
\hline \multirow{4}{*}{$\begin{array}{c}\text { Bio } \\
\text { fertilizer } \\
\text { (1) }\end{array}$} & T1 & 34.2 & 34.4 & 26.1 & 26.4 & 22.3 & 22.3 & 15.06 & 15.4 & 10.09 & 10.2 & 202 & 204 & 168.6 & 168.5 & 10.23 & 10.5 \\
\hline & T2 & 34.1 & 34.3 & 26.1 & 26.4 & 22.1 & 22.4 & 15.2 & 15.4 & 10.1 & 10.2 & 203 & 204 & 168 & 168.3 & 10.3 & 10.54 \\
\hline & T3 & 34.1 & 34.5 & 26.2 & 26.2 & 22.2 & 22.3 & 15.07 & 15.43 & 10.2 & 10.3 & 204 & 205 & 168 & 168.1 & 10.2 & 10.42 \\
\hline & Mean & 34.13 & 34.4 & 26.13 & 26.33 & 22.2 & 22.33 & 15.11 & 15.41 & 10.13 & 10.23 & 203 & 204.33 & 167.2 & 168.3 & 10.24 & 10.48 \\
\hline \multirow{4}{*}{$\begin{array}{c}\text { Chemical } \\
\text { fertilizer } \\
\text { (2) }\end{array}$} & T4 & 34.06 & 34.3 & 26.1 & 26.3 & 22.09 & 22.1 & 15 & 15.4 & 10.2 & 10.2 & 201.3 & 205 & 167.3 & 167.2 & 10.2 & 10.4 \\
\hline & T5 & 34.1 & 34.2 & 26.2 & 26.34 & 22.2 & 22.3 & 15.1 & 15.2 & 10.1 & 10.3 & 203 & 204 & 167.2 & 167.1 & 10.1 & 10.5 \\
\hline & T6 & 34.1 & 34.1 & 26.09 & 26.2 & 22.1 & 22.4 & 15.2 & 15.4 & 10 & 10.1 & 202 & 203 & 167.1 & 167 & 10.3 & 10.4 \\
\hline & Mean & 34.086 & 34.2 & 26.13 & 26.28 & 22.13 & 22.14 & 15.1 & 15.33 & 10.1 & 10.2 & 202.1 & 204 & 167.2 & 167.1 & 10.2 & 10.43 \\
\hline \multirow{4}{*}{$\begin{array}{c}\text { Mixture } \\
(1+2)\end{array}$} & T7 & 34.08 & 34.2 & 26.1 & 26.3 & 22.3 & 22.2 & 15 & 15.3 & 10.1 & 10.2 & 202 & 203 & 167.4 & 167.2 & 10.16 & 10.3 \\
\hline & T8 & 34.1 & 34.24 & 26.08 & 26.2 & 22.05 & 22.2 & 15.1 & 15.32 & 10.1 & 10.1 & 202 & 204 & 167.2 & 167.1 & 10.2 & 10.41 \\
\hline & T9 & 34.14 & 34.13 & 26.2 & 26.1 & 22.06 & 22.1 & 15.07 & 15.1 & 10.2 & 10.3 & 203 & 204 & 167 & 167 & 10.07 & 10.32 \\
\hline & Mean & 34.106 & 34.19 & 26.12 & 26.2 & 22.13 & 22.16 & 15.056 & 15.24 & 10.13 & 10.2 & 202.33 & 203.66 & 167.2 & 166.8 & 10.143 & 10.343 \\
\hline \multicolumn{2}{|c|}{ Control } & 34 & 34.1 & 26 & 26.1 & 22 & 22.1 & 15 & 15.1 & 10 & 10.1 & 201 & 201.1 & 166.2 & 166.4 & 10.1 & 10 \\
\hline
\end{tabular}


Table (3): Effect of different fertilizers on length $(\mu \mathrm{m})$ of different types of sensilla male B. mori L. during 2014 \& 2015 seasons

\begin{tabular}{|c|c|c|c|c|c|c|c|c|c|c|c|c|c|c|c|c|c|}
\hline \multirow{3}{*}{$\begin{array}{c}\text { Type } \\
\text { fertilizer }\end{array}$} & & \multicolumn{4}{|c|}{ Sensilla trichodea } & \multicolumn{4}{|c|}{ S. basiconica } & \multicolumn{2}{|c|}{ S. Coeloconica } & \multicolumn{4}{|c|}{ S. chaetica } & \multicolumn{2}{|c|}{ S. styloconica } \\
\hline & & \multicolumn{2}{|c|}{ Type A } & \multicolumn{2}{|c|}{ Type B } & \multicolumn{2}{|c|}{ Type A } & \multicolumn{2}{|c|}{ Type B } & \multirow[b]{2}{*}{$\underset{\text { จิ }}{\stackrel{ \pm}{2}}$} & \multirow[b]{2}{*}{ 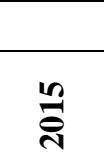 } & \multicolumn{2}{|c|}{ Type A } & \multicolumn{2}{|c|}{ Type B } & \multirow[b]{2}{*}{ ন্ } & \multirow[b]{2}{*}{$\stackrel{\text { 물 }}{\text { ก }}$} \\
\hline & & $\frac{\nabla}{\text { จิ }}$ & 농 & $\underset{\sim}{\stackrel{D}{\sim}}$ & $\stackrel{\text { ำ }}{\stackrel{2}{2}}$ & $\frac{⿱}{\text { จ }}$ & 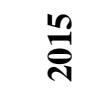 & 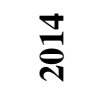 & $\stackrel{\text { ำ }}{\text { จ }}$ & & & $\underset{\text { จे }}{\mathbb{V}}$ & $\stackrel{\text { ำ }}{\text { ก }}$ & 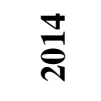 & ำ & & \\
\hline \multirow{4}{*}{$\begin{array}{c}\text { Bio } \\
\text { fertilizer } \\
(1)\end{array}$} & T1 & 35.4 & 35.6 & 27.3 & 27.5 & 24.4 & 24.4 & 16.46 & 16.5 & 11.19 & 11.3 & 205 & 206 & 169.6 & 170.6 & 11.85 & 11.94 \\
\hline & T2 & 34.84 & 35.14 & 26.71 & 27.4 & 23.3 & 24.4 & 16.4 & 16.42 & 11.14 & 11.25 & 204 & 205 & 169 & 170.2 & 11.7 & 11.5 \\
\hline & T3 & 34.1 & 34.4 & 26.2 & 26.3 & 22.2 & 23.3 & 15.27 & 15.41 & 10.61 & 10.51 & 204 & 204 & 168 & 169 & 11.52 & 11.2 \\
\hline & Mean & 34.78 & 35.04 & 26.73 & 27.06 & 22.3 & 23.3 & 16.04 & 16.11 & 11.096 & 11.02 & 204.33 & 205 & 168.86 & 169.93 & 11.69 & 11.54 \\
\hline \multirow{4}{*}{$\begin{array}{c}\text { Chemical } \\
\text { fertilizer } \\
\text { (2) }\end{array}$} & T4 & 34.86 & 35.5 & 27.3 & 27.3 & 23.19 & 23.3 & 16 & 16.4 & 11.2 & 11.4 & 202.3 & 206 & 168.3 & 170.2 & 11.6 & 11.4 \\
\hline & T5 & 34.51 & 34.8 & 26.9 & 27.14 & 23.1 & 23.3 & 16.1 & 16.2 & 11.1 & 11.3 & 203.8 & 205 & 168.2 & 169.1 & 11.1 & 11.5 \\
\hline & T6 & 34.31 & 34.8 & 25.9 & 26.82 & 22.91 & 23.23 & 15.92 & 16.2 & 11 & 11.1 & 203.5 & 203 & 168.1 & 168 & 11.3 & 11.4 \\
\hline & Mean & 34.56 & 35.03 & 26.7 & 27.08 & 23.07 & 22.14 & 16.01 & 16.26 & 11.1 & 11.2 & 203.2 & 204.66 & 168.2 & 169.1 & 11.33 & 11.43 \\
\hline \multirow{4}{*}{$\begin{array}{c}\text { Mixture } \\
(1+2)\end{array}$} & T7 & 34.88 & 34.52 & 27.1 & 27.3 & 22.93 & 22.2 & 16 & 16.3 & 11.1 & 11.2 & 203 & 205 & 168.4 & 168.6 & 11.6 & 11.83 \\
\hline & T8 & 34.43 & 34.24 & 26.98 & 26.76 & 22.85 & 22.2 & 16.1 & 16.32 & 11.1 & 11.1 & 202.8 & 204 & 168.2 & 169.1 & 11.2 & 11.21 \\
\hline & T9 & 34.34 & 34.43 & 26.2 & 26.31 & 22.66 & 22.1 & 15.87 & 16.11 & 10.92 & 10.39 & 203 & 204 & 168 & 168 & 10.97 & 10.92 \\
\hline & Mean & 34.55 & 34.39 & 26.76 & 26.79 & 22.81 & 22.16 & 15.99 & 16.24 & 11.04 & 10.89 & 202.93 & 204.33 & 168.2 & 166.56 & 11.25 & 11.31 \\
\hline \multicolumn{2}{|c|}{ Control } & 34.3 & 34.4 & 26.4 & 26.5 & 22.5 & 22.3 & 15.4 & 15.5 & 10.4 & 10.8 & 201.5 & 202 & 167 & 166.5 & 11.1 & 11.5 \\
\hline
\end{tabular}


classified as nonolfactory sensilla in B. mori (McIver 1973, 1974; Boo and McIver 1975, 1976; Davis and Sokolove 1975; Steinbrecht, 1988).

\section{Sensilla squamiformia}

The dorsal side of $B$. morei flagellum bears squamiformia sensilla (scale like procces) which average $65 \mu \mathrm{m}$ in length (Fig $1 \mathrm{E} \& \mathrm{~F}$ ).

Most sensilla on silkmoth antennae are olfactory, in the male; about $70 \%$ of these are sensitive to sex pheromone. The s. trichodea sensitive to pheromone contain two sensory neurons of which one is sensitive to bombykol while the other is sensitive to bombykal (Kaissling et al., 1978). In females, the most abundant type of olfactory s. trichodeum contains two receptor cells highly responsive to two plant odours, linalool and benzoic acid (Heinbockel \& Kaissling, 1996 and de Brito Sanchez and Kaissling, 2005). Other olfactory sensilla also respond to plant odours. The male sensilla trichodea has a receptor cell responding to the bombykol pheromone component. The sensilla trichodea of the females contained specialized receptor cells responding to certain terpenoids, the most frequent being the nerolidol-sensitive cell. Cells of the sensilla coeloconica responded to aliphatic aldehydes andacids de Brito Sanchez, 1996 and Ziesmann et al., 2000.

Effect of different fertilizers and their mixtures on the fresh cocoon weight, shell cocoon weight and size of sensilla of mulberry silkworm is presented in Tables $1,2 \& 3$. No significant differences were found between control, chemical, bio-fertilizers and their mixture for weights of fresh cocoon, cocoon shell, while the size of sensilla showed significant difference. Bio-fertilizers increased fresh cocoon weight; cocoon shell weight compared with the control and was reflected in the size of sensilla styloconica (Tables 2\&3). The application Bio-fertilizer resulted in better values for silk gland length, pupation ratio, cocoon percentage and larval weight (ElKahyat 2013. These results are in agreement with those obtained by Rao et al., (2008), Mary and Saravanan (2010) and Waktole and Bhaskar (2012) who reported that nutrition plays a pivotal role in sericulture. It improves the growth, development, health, feed consumption and conversion of silkworm thereby improving the commercial traits.

\section{References}

Blaney W. M. (1974) Electrophysiological responses of the terminal sensilla on the maxillary palps of Locusta migratoria to some electrolytes and nonelectrolytes. J. Exp. Biol. 60: 275-293

Boo, K.S. and McIver, S. B. (1975). Fine structure of sunken thick-walled pegs (sensilla ampullacea and coeloconica) on the antennae of mosquitoes. Can J Zool; 53:262-266.

Boo, K.S. and McIver, S. B. (1976). Fine structure of surface and sunken grooved pegs on the antenna of female Anopheles stephensi (Diptera: Culicidae). Can J Zool; 54:235-244.
Cuperus, P. L. (1983). Distribution of antennal sense organs in male and female ermine moth, Yponomeuta vigintipunctatus (Retzius) (Lepidoptera: Yponomeutidae). Int J Insect Morphol Embryol; 12:59-66.

Cuperus, P. L., Thomas, G. and Den Otter, C. J. (1983). Interspecific variation and sexual dimorphism of antennal receptor morphology, in European Yponomeuta (Latreille) (Lepidoptera: Yponomeutidae). Int J Insect Morphol Embryol; 12:67-78.

Cuperus, P. L. (1985a). Inventory of pores in antennal sensilla of Yponomeuta spp. (Lepidoptera: Yponomeutidae) and Adoxophyes orana F.v.R (Lepidoptera: Tortricidae). Int J Insect Morphol Embryol; 14:347-359.

Cuperus, P. L. (1985b). Ultrastructure of antennal sense organs of small ermine moths, Yponomeuta spp (Lepidoptera: Yponomeutidae). Int J Insect Morphol Embryol; 14:179-191.

Davis, E. E. and Sokolove, P.G. (1975). Temperature responses of antennal receptors of the mosquito, Aedes aegypti. J. comp. Physiol., 96, 223-236.

de Brito Sanchez, Marı'a Gabriela and Kaissling, Karl-Ernst (2005).Inhibitory and Excitatory Effects of Iodobenzene on the Antennal Benzoic Acid Receptor Cells of the Female Silk Moth Bombyx mori L. Chem. Senses 30: 435-442.

de Brito Sanchez, M. G. (1996). Structureactivity relationships of antennal benzoic-acid receptor cell of female silkmoth Bombyx mori L. In Elsner, L. and Schnitzler, H.U. (eds), Proceedings of the $24^{\text {th }}$ Goettingen Neurobiology Conference. Thieme, Stuttgart, vol. II, p. 280.

Den Otter, C. J.; Schuil, H. A. and Sander Van Oosten, A. (1978). Reception of host-plant odours and female sex pheromone in Adoxophyes orana (Lepidoptera: Tortricidae): electrophysiology and morphology. Entomol Exp Appl; 24:370-378.

El-Khayat, E. F.; Gaaboub, I. A.; Omer, R. E. M., Ghazey, U. M. and El-Shewy, A. M. (2013). Impact of Bio and Inorganic Fertilizer Treatments on Economic Traits of Mulberry Silkworm (Bombyx mori L.). Academic Journal of Entomology 6 (1): 01-06, 2013.

Gaaboub I. A. and Hustert, H. (1998). Motor response to chemical stimulation of tarsal sensills in locusts. Proceeding of the $26^{\text {th }}$ Göttingen Neurbiology conference, Vol. 1: p. 336

Gaaboub I. A. (2000). Neural processing of chemosensory information from the locust legs. Ph.D. Goettingen University, Germany.

Gaaboub I. A., Schuppe H. and Newland, P. L. (2005). Receptor sensitivity underlies variability of chemosensory evoked avoidance movements of the legs of locusts. J Comp Physiol 191:281-289.

Gaaboub, I. A. and Tousson, E. (2005). Ultrastructure and Electrophysiological studies on the sense 
organs of the cotton leaf worm Spodoptera littoralis (Boisd.). Egypt. J. Exp. Biol. (Zool.), 1: 167 - 176.

Gaaboub, I. A. and Tousson, E. M. (2010) Oviposition and Electrophysiological responses of Spodoptera littoralis to castor bean oil (Ricinus communis) seeds and leaf extracts. Egypt. J. Exp. Biol. (Zool.), 6(1): 55 - 60 (2010)

Hallberg, E. (1981). Fine-structural characteristics of the antennal sensilla of Agrotis segetum (Insecta: Lepidoptera). Cell Tiss Res; 218:209-218.

Heinbockel, T. and Kaissling, K. E. (1996). Variability of olfactory receptor neuron responses of female silkmoths (Bombyx mori L.) to benzoic acid and ( \pm )linalool. J Insect Physiol; 42:565-578.

Hunger, T. and Steinbrecht, R. A. (1998) Functional morphology of a double-walled multiporous olfactory sensillum: the sensillum coeloconicum of Bombyx mori (Insecta, Lepidoptera) Tissue \& Cell, 199830 (1) 1429

Jadhav, S. N.; Patil, G. M. and Glaraddi, R. S. (2000). Effect of organic and inorganic manures and their combinations on mulberry and its impact on silkworm production. Karanatka J. Agric. Sci., 13: 744-749.

Kalogianni E. (1996). Morhology and physiology of abdominal intersegmental interneurones in the locust with mechanosensory inputs from ovipositor hair receptors. J Comp Neuro 366: 656-673.

Kaissling, K. E.; Kasang, G.; Bestmann, H. J.; Stransky, W. and Vostrowsky, O. (1978). A new pheromone of the silkworm moth Bombyx mori: sensory pathway and behavioral effect. Naturwissenschaften 65, 382-384.

Kaissling, K. (2009). The sensitivity of the insect nose: The example of Bombyx mori, chapter 3, pp.45-52, in 'Biologically Inspired Signal Processing for Chemical Sensing', 2009, XIV, Springer.

Keil T. A. (1984a). Reconstruction and morphometry of silkmoth olfactory hairs: a comparative study of sensilla trichodea on the antennae of male Antheraea polyphemus and Antheraea pernyi (Insecta, Lepidoptera). Zoomorphology; 104:147-156.

Keil T. A. (1989). Fine structure of the pheromone-sensitive sensilla on the antenna of the hawkmoth, Manduca sexta. Tissue Cell; 21:139-151.

Lee J. K. and Strausfeld, N. J. (1990). Structure, distribution and number of surface sensilla and their receptor cells on the olfactory appendage of the male moth, Manduca sexta. J Neurocytol; 19:519-538.

$$
\text { LEO-UIF: Leo 438VP. }
$$
http://www.technicalsalessolutions.com/item_description.p $\underline{\mathrm{hp} \text { ?ID }=53}$

McIver, S. B. (1973). Fine structure of antennal sensilla coeloconica of culicine mosquitoes. Tiss. Cell, 5, 105-112.

McIver, S. B. (1974). Fine structure of antennal grooved pegs of the mosquito, Aedes aegypti. Cell Tissue Res; 153:327-337.
Mary, L. C. L. and Saravanan, N. A. (2010). Influence of bio-fertilizers on mulberry and silkworm production. Journal of Ecobiology, 27(1/2): 197-199.

Nasreen, A.; Cheema, G.M. and Ashfaq, M. (1999). Rearing of milk Bombyx mori L. on alternative food parts. Pakistan. Journal of Biological Sciences, 2: 843-845.

Newland, P. L.; Rogers, S. M.; Gaaboub, I. and Matheson, T. (2000). Parallel Somatotopic Maps of gustatory and mechanosensory neurons in the central nervous system of an insect. J Comp Neurol 275: 82-96.

Pophof, B. (1997). Olfactory responses recorded from sensilla coeloconica of the silkmoth Bombyx mori. Physiolosical Entomology, 22, 239-248.

Rao, T. V. S. S.; Reddy, B. K.; Rao, J.V.K.; Raju, A.H.; Latha, K. L. and Jayaraj, S. (2008). Studies on combined effect of biofertilizers and in situ green manuring on leaf yield in mulberry. Indian Journal of Sericulture, 47(1): 16-19.

Sanes, J. R. and Hildebrand, J. G. (1976). Structure and development of antennae in a moth, Manduca sexta. Dev Biol; 51:282-299.

Shields, V. D. C. and Hildebrand, J. G. (2001). Responses of a population of antennal olfactory receptor cells in the female moth Manduca sexta to plant-associated volatile organic compounds. J Comp Physiol A; 186:11351151.

Schneider, D. and Steinbrecht R. A. (1968). Checklist of insect olfactory sensilla. Symp Zool Soc London; 23:279-297.

Singheal, B. K., Malav, R.; Sarkar, A. and Datta, R. K. (1999). Nutritional disorders of mulberry (Morus spp.): III- leaf nutrient guide for secondary nutrients. Sericologia, 39(40): 599-609.

Staedler, E.; Renwick, J. A.; Radke, C. D. and Sachdev-Gupta, K. (1995). Tarsal contact chemoreceptor response to glucosinolates and cardenolides mediating oviposition in Pieris rapae. Physical Entomol 20: 105-121

Steel, R.; Torrie, J. and Dickey, D. (1997). Principles and Procedures of Statistics: A Biometrical Approach, 3 Ed., McGraw-Hill, New York, NY.

Steinbrecht, R. A. (1973). Der Feinbau olfaktorischer Sensillen des Seidenspinners (Insecta, Lepidoptera). Rezeptorfortsätze und reizleitender Apparat. Z Zellforsch; 139:533-565.

Steinbrecht, R. A. (1980). Cryofixation without cryoprotectants. Freeze substitution and freeze etching of an insect olfactory receptor. Tissue Cell 1980; 12:73-100.

Steinbrecht, R. A. and Gnatzy, W. (1984). Pheromone receptors in Bombyx mori and Antheraea pernyi. I. Reconstruction of the cellular organization of the sensilla trichodea. Cell Tissue Res; 235:25-34.

Steinbrecht, R. A. (1988). An anomalous sensillum chaeticum with a double set of cilia and outer dendritic segments in Bombyx mori L. (Lepidoptera: Bombycidae). Int J Insect Morphol Embryol, 17, 83-87.

Steinbrecht, R. A.; Lee, J. K.; Altner, H. and Zimmermann, B. (1989). Volume and surface of receptor and auxiliary cells in hygro-/thermoreceptive sensilla of 
moths (Bombyx mori, Antheraea pernyi, and A.polyphemus). Cell Tissue Res; 255:59-67.

Steinbrecht, R. A. (1989). The fine structure of thermo-/hygrosensitive sensilla in the silkmoth Bombyx mori: Receptor membrane substrate and sensory cell contacts. Cell Tissue Res. 255: 49-57.

Tousson, E.; Gaaboub, I. and Hustert, H. (1999). Response characteristics and specificity of

contact chemoreceptors from different sites in Locusta migratoria. Proceeding of the $27^{\text {th }}$ Göttingen Neurbiology conference, II: 348.

Tousson, E. and Gaaboub, I. A. (2004). neuroanatomical and electrophysiological relationships between sensory afferent arborizations in the locust paraproctal sensory systems. The $3^{\text {rd }}$ Pros ICBS, 3: $595-$ 614.

Van der Pers, J. N. C. and Den Otter, C. J. (1978). Single cell responses from olfactory receptors of small ermine moths, Yponomeuta spp. (Lepidoptera: Yponomeutidae). Int J Insect Morphol Embryol; 9:15-23.

Waktole, S. and Bhaskar, R. N. (2012). Effect of bio-inoculants applied to M5 mulberry under rain-fed condition on growth and cocoon traits performance of silkworm, Bombyx mori L. Momona Ethiopian Journal of Science, 4(2): 29-39.

White, P. R. and Chapman, R. F. (1990). Tarsal chemoreception in the polyphagous grasshopper Schistocerca americana. Behavioral assays, sensilla distributions and electrophysiology. Physiol. Entomol., 15: 105-121.

Ziesmann, J., Valterova, I., Haberkorn, K., de Brito Sanchez, M.G. and Kaissling, K.E. (2000) Chemicals in laboratory room air stimulate olfactory neurons of female Bombyx mori. Chem. Senses, 25, 31-37 